\title{
Agriculture Information Management Behaviour of Aonla Growers
}

\author{
Saroj Choudhary* \\ Department of extension education, SKNCOA, Jobner, India \\ *Corresponding author
}

\section{A B S T R A C T}

\begin{tabular}{|l|}
\hline Ke y w or d s \\
Agriculture \\
information, \\
Seeking, Evaluation, \\
Preservation, \\
$\begin{array}{l}\text { Utilisation, } \\
\text { Dissemination and } \\
\text { behaviour }\end{array}$ \\
\hline Article Info \\
\hline $\begin{array}{l}\text { Accepted: } \\
\text { 30 October 2017 } \\
\text { Available Online: } \\
\text { 10 December } 2017\end{array}$ \\
\hline
\end{tabular}

India has one of the largest and most complex public systems for generation, testing and transfer of agricultural information. It is the information behaviour of the farmers, which can promote and spread the results obtained in the laboratories for their better utilization in farming community. Aonla growers information management from different sources and channels of agriculture information which have brought the aonla growers and scientists close to understand the suitability of the technologies. The Semi-Arid Eastern Plains Zone (IIIa) of Rajasthan has highest area and production under aonla cultivation. There are so many agricultural institutions, which are engaged in the research on aonla growers problems and transfer of technology to the aonla growers.

\section{Introduction}

An improvement and strengthening of agricultural infrastructure needed to all the levels of supply chain. Shrinking extension is another component of infrastructure that needs attention. After the green revolution in the mid-sixties there has been no major technological innovation, which could give a fresh impetus to agricultural productivity, insufficient extension services and poor access to information further widen the gap in the adoption of technology and lead to poor productivity levels. A push towards higher productivity will require information based, decision making agricultural system. This is often described as the next great evolutionary step in agricultural. Today's farmers desire not only the meals for their families from their hard sweat but also surplus production which can sold in the market to get sufficient money to fulfill the daily requirements. According to economic reforms in the country each and every sector has changed its strategies in view of global competition.

Among the various sources of information mass media is an important one which consists of newspapers, magazines, traditional media, radio, TV and information technology which have proven to be the most powerful opinion makers in this information technology era. They cover more people in less time with minimum cost. This strength of mass media is of great help to extension workers in providing cost effective and efficient services 
to the farmers. Computers are the greatest discovery in the recent times. Internet has made the world into a global village and provides the channel for exchange of information quickly. Unfortunately the usage of information technology as a powerful medium in the field of agriculture is yet to take place effectively.

\section{Materials and Methods}

\section{Agriculture Information Seeking Behaviour (AISB)}

The procedure suggested by Bhople (1995), Jyothi (2000) and followed by Ravindra Kumar (2006) was modified with little modifications as suggested by the experts and followed for measuring the AISB of respondents. Based on the available literature, discussion with extension functionaries all possible farm information sources were exhaustively listed under different heading namely personal contact, group contact and mass media sources. Frequency of contact of different information sources was measured on a three point continuum namely, 'regularly', 'occasionally' and 'never' with a scoring of 2, 1 and 0 respectively.

\section{Agriculture Information Evaluation Behaviour (AIEB)}

The first component of AIEB i.e. the act performed for evaluation of information by aonla growers was measured in terms of 13 different acts likely to be performed by the individual for the evaluation of the information and consequent acceptance of farm information. Each act performed by an individual was assigned a numerical score. Frequency of evaluation of different information sources was measured on a four point continuum namely, 'regularly', 'occasionally', 'rarely', and 'never' with a scoring of 3,2,1 and 0 respectively
The second component of AIEB i.e. the consideration of different parameters used for evaluation of information by anola growers was measured in terms of 7 different considerations likely to be performed by the individual for the evaluation of the information and consequent acceptance of farm information. Each consideration by an individual was assigned a numerical score. Frequency of evaluation of different information sources was measured on a threepoint continuum i.e. 'mostly', 'sometimes' and 'never' with a scoring of 3,2 and 1 respectively.

The third component of AIEB i.e. the action taken by anola growers before using the information was measured in terms of 4 different actions likely to be performed by the individual for the evaluation of the information and consequent acceptance of farm information.

Each action taken by an individual was assigned a numerical score. Frequency of evaluation of different information sources was measured on a three- point continuum i.e. 'mostly', 'sometimes' and 'never' with a scoring of 3, 2 and 1 respectively.

\section{Agriculture Information Preservation Behaviour (AIPB)}

The Information Preservation Behaviour act performed by anola growers was measured in terms of 8 different acts performed or likely to be performed by the individual for the storage of the information and consequent acceptance of farm information. Each act performed by an individual was assigned a numerical score. Frequency of storage of different information sources was measured on a four point continuum namely, 'up to high extent', 'up to medium extent', 'up to low extent', and 'never' with a scoring of $3,2,1$ and 0 respectively. 


\section{Agriculture Information Utilisation Behaviour (AIUB)}

The operations carried out by using the information of anola growers was measured in terms of 12 different operations likely to be performed by the individual for the utilization of the information and consequent acceptance of farm information. Each operation by an individual was assigned a numerical score. Frequency of utilisation of different information sources was measured on a four point continuum namely, 'regularly', 'occasionally' and 'never' 'with a scoring of 2,1 and 0 respectively.

\section{Agriculture Information Dissemination Behaviour (AIDB)}

The information dissemination behaviour of anola growers was measured in terms of 8 different acts of disseminating information likely to be performed by the individual for the dissemination of the information. Each acts of disseminating information by an individual was assigned a numerical score. Frequency of dissemination of different information sources was measured on a three point continuum namely, 'regularly', 'occasionally' and 'never' with a scoring of 2 , 1 and 0 respectively.

\section{Results and Discussion}

The Agriculture Information Management Behaviour in the present study has been conceptualised as a composite measure of information seeking, evaluation, preservation, and utilisation and dissemination behaviour of the individual grower. In view of this conceptualisation, the Information Management Behaviour of the respondents was the sum of all the five dimensions viz., Agriculture Information Seeking Behaviour, Agriculture Information Evaluation Behaviour, Agriculture Information
Preservation/ Storage Behaviour, Agriculture Information Utilisation Behaviour and Agriculture Information Dissemination Behaviour.

The Agriculture Information Management Behaviour was measured by the scale developed by Raju (2005) with slight modification as suggested and approved by experts.

The schedule was standardized by expert opinion from the SMS's of Department of Extension Education, Department of Horticulture and Agriculture Officers of Agriculture Department.

The score of Agriculture Information Management Behaviour of a particular farmer was obtained by adding the scores obtained by that particular farmer in all the components of AgricultureInformation Management Behaviour viz., Agriculture Information Seeking Behaviour (AISB), Agriculture Information Evaluation Behaviour (AIEB), Agriculture Information Preservation Behaviour (AIPB), Agriculture Information Utilisation Behaviour (AIUB) and Agriculture Information Dissemination Behaviour (AIDB) as perceived by the aonla growers

The data regarding Agriculture Information Management Behaviour of aonla growers has been presented under the following heads:-

Distribution of aonla growers according to their different levels of Agriculture Information Management Behaviour

Information Seeking Behaviour of the aonla growers with respect to their personal contact sources and channels of information.

Information Seeking Behaviour of the aonla growers with respect to their group contact sources and channels of information. 
Information Seeking Behaviour of the aonla growers with respect to their mass media sources and channels of information.

Information Evaluation Behaviour of the aonla growers with respect to their acts performed for evaluation of information. Information Evaluation Behaviour of the aonla growers with respect to their consideration of different parameters used for evaluation of information.

Information Evaluation Behaviour of the aonla growers with respect to their action taken by anola growers before using the information.

Information Preservation Behaviour of the aonla growers.

Information Utilization Behaviour of the aonla growers.

Information Dissemination Behaviour of the aonla growers.

\section{Distribution of aonla growers according to their different levels of Agriculture Information Management Behaviour}

The Agriculture Information Management Behaviour of aonla growing farmers and farm women was calculated by summing the scores obtained by that particular farmer in all the five components of AIMB which AISB, AIEB, AIPB, AIUB and AIDB. Then the aonla growing farmers and farm women were categorized into five different levels of AIMB namely, very low (0-20 per cent), low (20-40 per cent), medium (40-60 per cent), high (6080 per cent) and very high (80-100 per cent). Further the $X^{2}$ value between the frequencies of aonla growing farmers and farm women in different levels was calculated to find out the significance the agreement between the aonla growing farmers and farm women.
The data presented in Table 1 indicated that majority of aonla growing farmers and farm women (55.83 per cent and 57.50 per cent respectively) were having medium level of AIMB, whereas 6.67 per cent, 35.00 per cent and 2.50 per cent aonla growing farmers and 10.00 per cent, 31.67 per cent, and 0.83 per cent aonla growing farm women were having low, high and very high level of AIMB respectively and none of the aonla growing farmers and farm women were having very low level of AIMB.

The calculated value of Chi-square $\left(\chi^{2}\right)$ test was found to be 184.708 , which is more than its tabulated value (9.488) at 5 per cent level of significance. Hence the null hypothesis was rejected and alternate hypothesis was accepted. This leads to the conclusion that there is a highly significant agreement between the aonla growing farmers and farm women of the aonla growers with regard to their AIMB.

\section{Agriculture Information Seeking Behaviour of the aonla growers in Jaipur and Ajmer districts with respect to their personal contact sources and channels of information}

The data related with Agriculture Information Seeking Behaviour of the aonla growing farmers and farm women with respect to their sources of personal contact is incorporated in Table 1.1 shows that calculated Wilcoxen ' $Z$ ' value for the personal contact sources viz. 'personal contact with $\mathrm{AO} / \mathrm{AAO}$ ', 'personal Contact with $\mathrm{AHO} / \mathrm{HA}$ ', 'personal letter', 'office call', 'telephone call', 'contact with progressive farmers', 'contact with Agro Service Centers', 'friends and neighbours', 'farm and home visit', 'farmers call and farm clinic' were more than the tabulated value at 5 per cent level of significance. Hence, the null hypothesis was rejected and alternate hypothesis was accepted, which leads to the 
conclusion that there is a significant difference between aonla growing farmers and farm women with respect to their Agriculture Information Seeking Behaviour regarding these personal contact sources and channels of information. Whereas the calculated Wilcoxen ' $Z$ ' value for the personal contact sources viz. 'university/ KVK scientist' and 'private extension officer' were less than the tabulated value at 5 per cent level of significance. Hence, the null hypothesis was accepted and alternate hypothesis was rejected, which leads to the conclusion that there is no significant difference between aonla growing farmers and farm women with respect to their Agriculture Information Seeking Behaviour regarding these personal contact sources and channels of information.

The data presented in Table 1.1 indicates that for aonla growing farmers and farm women "contact with progressive farmers" (MPS 80.65 and 76.25 respectively) and "friends and neighbours" (MPS 77.85 and 74.05 respectively) were the major personal contact sources of agriculture information used by majority of the anola growers and accorded first and second ranks respectively. It also revealed that for aonla growing farmers "farm clinic" (MPS 60.95) and farm women "farmers cell" (MPS 61.45) were the least preferred information source as perceived by the respondents.

\section{Agriculture Information Seeking Behaviour of the aonla growers in Jaipur and Ajmer districts with respect to their sources of group contact}

The data related with Agriculture Information Seeking Behaviour of the aonla growing farmers and farm women with respect to their sources of group contact incorporated in Table 1.2 shows that calculated Wilcoxen ' $Z$ ' value for the group contact sources viz. 'group discussion and meeting', 'training programmes', 'discussion with fellow farmers', 'field day and field trip' were more than the tabulated value at 5 per cent level of significance. Hence, the null hypothesis was rejected and alternate hypothesis was accepted, which leads to the conclusion that there is a significant difference between aonla growing farmers and farm women with respect to their Agriculture Information Seeking Behaviour regarding these group contact sources and channels of information. Whereas the calculated Wilcoxen ' $Z$ ' value for the group contact sources 'study tour' was less than the tabulated value at 5 per cent level of significance.

Hence, the null hypothesis was accepted and alternate hypothesis was rejected, which leads to the conclusion that there is no significant difference between aonla growing farmers and farm women with respect to their Agriculture Information Seeking Behaviour regarding these group contact source and channel of information.

The data presented in Table 1.2 indicates that for aonla growing farmers "group discussion and meeting" (MPS 71.25) and for farm women "discussion with follow farmers" (MPS 61.13) were the major group contact sources of agriculture information used by majority of the anola growers and accorded first rank, whereas for aonla growing farmers "discussion with follow farmers" (MPS 70.57) and for farm women "group discussion and meeting" (MPS 56.25) were the major group contact sources of agriculture information used by majority of the anola growers and accorded second rank respectively.

It also revealed that for aonla growing farmers and farm women "study tour" (MPS 59.90 and 50.40) was the least preferred information sources. 
Agriculture Information Seeking Behaviour of the aonla growers in Jaipur and Ajmer districts with respect to their sources of mass media

The data related with Agriculture Information Seeking Behaviour of the aonla growers of farmers and farm women with respect to their sources of mass media were incorporated in Table 1.3 shows that calculated Wilcoxen ' $Z$ ' value for the mass media sources viz. 'television', 'newspaper', 'agricultural magazine', 'krishi mela / exhibition', 'internet', 'mobile phone' and 'agriculture journal, magazine' were more than the tabulated value at 5 per cent level of significance. Hence, the null hypothesis was rejected and alternate hypothesis was accepted, which leads to the conclusion that there is a significant difference between aonla growing farmers and farm women with respect to their Agriculture Information Seeking Behaviour regarding these mass media sources and channels of information.

Whereas the calculated Wilcoxen ' $Z$ ' value for the mass media sources viz. 'radio' and 'farm publication' were less than the tabulated value at 5 per cent level of significance.

Hence, the null hypothesis was accepted and alternate hypothesis was rejected, which leads to the conclusion that there is no significant difference between aonla growing farmers and farm women with respect to their Agriculture Information Seeking Behaviour regarding these mass media source and channel of information.

The data presented in Table 1.3 indicates that for aonla growing farmers and farm women "Television" (MPS 70.97 and 60.71 respectively) was the major mass media source of agriculture information used by majority of the anola growers and accorded first rank, whereas for the aonla growing farmers "Radio" (MPS 68.94) and for farm women "Krishi Mela/Exhibition (MPS 58.35) were the major mass media sources of agriculture information used by majority of the anola growers and accorded second rank respectively. It also revealed that for aonla growing farmers and farm women "Agriculture journal, magazine" (MPS 58.25 and 48.38 respectively) was the least preferred information sources.

\section{Agriculture Information evaluation behaviour of the aonla growers with respect to their acts performed for evaluation of information}

The data related with Agriculture Information Evaluation Behaviour of the aonla growing farmers and farm women with respect to their acts performed for evaluation of information incorporated in Table 2.1 shows that calculated Wilcoxen ' $Z$ ' value for the acts performed for evaluation of information were incorporated in Table 5.2.1.3 shows that calculated Wilcoxen ' $Z$ ' value for the acts performed for evaluation of information viz. 'discussion with family members', 'discussion with neighbours and friends', 'discussion with progressive farmers', 'discussion with the staff of the horticulture dept. AHO/AS', 'discussion with the extension personnel of the Department of agriculture AO/AAO', 'discussion with the scientists of the university / KVK', 'in the light of past experience', 'discussion with private extension personal', 'discussion with the scientist' and 'considering with small scale trials' were more than the tabulated value at 5 per cent level of significance. Hence, the null hypothesis was rejected and alternate hypothesis was accepted, which leads to the conclusion that there is a significant difference between aonla growing farmers and farm women with respect to their Agriculture Information Evaluation 
Behaviour regarding these acts performed for evaluation of information. Whereas the calculated Wilcoxen ' $Z$ ' value for the acts performed for evaluation of information viz. 'considering its economic feasibility', 'judge it in relation to climatic condition' and 'accepted as such' were less than the tabulated value at 5 per cent level of significance.

Hence, the null hypothesis was accepted and alternate hypothesis was rejected, which leads to the conclusion that there is no significant difference between aonla growing farmers and farm women with respect to their Agriculture Information Evaluation Behaviour regarding these acts performed for evaluation of information.

The data presented in Table 5.2.2.1 indicates that for aonla growing farmers "Discussion with the staff of the horticulture department AHO/AS" (MPS 75.61) and for farm women "Discussion with neighbours and friends" (MPS 74.40) were the major act performed for evaluation of agriculture information used by majority of the anola growers and accorded first rank, whereas, for the aonla growing farmers "Discussion with progressive farmers" (MPS 75.00) and for farm women "Discussion with family members" (MPS 72.95) were the major acts performed for evaluation of agriculture information used by majority of the anola growers and accorded second rank respectively. It also revealed that for aonla growing farmers and farm women "accepted as such" (MPS 54.37 and 53.96 respectively) was the least preferred information source as perceived by the respondents.

It was observed that mass media sources such as radio, television, agril magazines and newspapers were consulted only when the farmers know that these sources covers needful information. Whereas majority of the respondents regularly use the Krishi mela, as a sources of information. Which is nearer to the study area and most of the farmers get the seeds and required information during Krishi mela, so farmers regularly participate in Krishi mela.

None of the respondents used the internet sources due to lack of knowledge, nonavailability of services in remote area and difficulty in accessing the internet.

\section{Agriculture Information Evaluation Behaviour of the aonla growers with respect to their consideration of different parameters used for evaluation of information}

The data related with Agriculture Information Evaluation Behaviour of the aonla growing farmers and farm women with respect to their consideration of different parameters used for evaluation of information incorporated in Table 2.2 shows that calculated Wilcoxen ' $Z$ ' value for the consideration of different parameters used for evaluation of information viz. 'profitability from innovations', 'method of doing planting', 'availability of inputs', 'predictability' and 'triability' were more than the tabulated value at 5 per cent level of significance

Hence, the null hypothesis was rejected and alternate hypothesis was accepted, which leads to the conclusion that there is a significant difference between aonla growing farmers and farm women with respect to their Agriculture Information Evaluation Behaviour regarding these considerations of different parameters used for evaluation of information. Whereas the calculated Wilcoxen ' $Z$ ' value for the consideration of different parameters used for evaluation of information viz. 'observability' and 'complexity' were less than the tabulated value at 5 per cent level of significance. 
Table.1 Distribution of aonla growing farmers and farm women according to their levels of Agriculture Information Management Behaviour

\begin{tabular}{|c|c|c|c|c|c|c|c|}
\hline \multirow{3}{*}{ S. No. } & \multirow{3}{*}{$\begin{array}{c}\text { Levels of Information } \\
\text { Management Behaviour }\end{array}$} & \multirow{2}{*}{\multicolumn{2}{|c|}{$\begin{array}{c}\text { Jaipur district } \\
(\mathrm{n}=160)\end{array}$}} & & & & $\mathrm{N}=240$ \\
\hline & & & & \multicolumn{2}{|c|}{$\begin{array}{c}\text { Ajmer district } \\
(n=80)\end{array}$} & \multicolumn{2}{|c|}{$\begin{array}{c}\text { Total respondents } \\
(\mathrm{N}=\mathbf{2 4 0})\end{array}$} \\
\hline & & $\begin{array}{c}\text { Farmers } \\
(\mathbf{n}=\mathbf{8 0})\end{array}$ & $\begin{array}{c}\text { Farm women } \\
(\mathbf{n}=\mathbf{8 0})\end{array}$ & $\begin{array}{c}\text { Farmers } \\
(n=40)\end{array}$ & $\begin{array}{c}\text { Farm } \\
\text { women } \\
(n=40)\end{array}$ & $\begin{array}{c}\text { Farmers } \\
(\mathbf{n}=\mathbf{1 2 0})\end{array}$ & $\begin{array}{c}\text { Farm } \\
\text { women } \\
(\mathrm{n}=120)\end{array}$ \\
\hline 1. & Very Low $(0-20$ per cent $)$ & $\begin{array}{c}0 \\
(0.00)\end{array}$ & $\begin{array}{c}0 \\
(0.00)\end{array}$ & $\begin{array}{c}0 \\
(0.00)\end{array}$ & $\begin{array}{c}0 \\
(0.00)\end{array}$ & $\begin{array}{c}0 \\
(0.00)\end{array}$ & $\begin{array}{c}0 \\
(0.00)\end{array}$ \\
\hline 2. & Low (20-40 per cent) & $\begin{array}{c}4 \\
(5.00)\end{array}$ & $\begin{array}{c}7 \\
(8.75)\end{array}$ & $\begin{array}{c}4 \\
(10.00) \\
\end{array}$ & $\begin{array}{c}5 \\
(12.50) \\
\end{array}$ & $\begin{array}{c}8 \\
(6.67)\end{array}$ & $\begin{array}{c}12 \\
(10.00)\end{array}$ \\
\hline 3. & Medium (40-60 per cent) & $\begin{array}{c}48 \\
(60.00)\end{array}$ & $\begin{array}{c}47 \\
(58.75)\end{array}$ & $\begin{array}{c}19 \\
(47.50)\end{array}$ & $\begin{array}{c}22 \\
(55.00)\end{array}$ & $\begin{array}{c}67 \\
(55.83)\end{array}$ & $\begin{array}{c}69 \\
(57.50)\end{array}$ \\
\hline 4 & High $(60-80$ per cent $)$ & $\begin{array}{c}26 \\
(32.50)\end{array}$ & $\begin{array}{c}25 \\
(31.25)\end{array}$ & $\begin{array}{c}16 \\
(40.00)\end{array}$ & $\begin{array}{c}13 \\
(32.50)\end{array}$ & $\begin{array}{c}42 \\
(35.00)\end{array}$ & $\begin{array}{c}38 \\
(31.67)\end{array}$ \\
\hline \multirow[t]{2}{*}{5} & Very high ( $80-100$ per cent) & $\begin{array}{c}2 \\
(2.50)\end{array}$ & $\begin{array}{c}1 \\
(1.25)\end{array}$ & $\begin{array}{c}1 \\
(2.50)\end{array}$ & $\begin{array}{c}0 \\
(0.00)\end{array}$ & $\begin{array}{c}3 \\
(2.50)\end{array}$ & $\begin{array}{c}1 \\
(0.83)\end{array}$ \\
\hline & Total & $\begin{array}{c}80 \\
(100.00)\end{array}$ & $\begin{array}{c}\mathbf{8 0} \\
(100.00)\end{array}$ & $\begin{array}{c}40 \\
(100.00)\end{array}$ & $\begin{array}{c}40 \\
(100.00)\end{array}$ & $\begin{array}{c}120 \\
(100.00)\end{array}$ & $\begin{array}{c}120 \\
(100.00)\end{array}$ \\
\hline
\end{tabular}

$\chi^{2}=184.708$ d.f. $=4$ Figures in parentheses indicate percentage

Table.2 Agriculture information seeking behaviour of the aonla growers with respect to their sources of personal contact

$\mathrm{N}=240$

\begin{tabular}{|c|c|c|c|c|c|c|c|c|c|c|c|c|c|c|}
\hline \multirow[t]{3}{*}{$\begin{array}{l}\text { S. } \\
\text { No. }\end{array}$} & \multirow{3}{*}{$\begin{array}{c}\text { Personal } \\
\text { contact } \\
\text { sources }\end{array}$} & \multicolumn{4}{|c|}{$\begin{array}{c}\text { Jaipur district } \\
(n=160)\end{array}$} & \multicolumn{4}{|c|}{$\begin{array}{c}\text { Ajmer district } \\
(n=80)\end{array}$} & \multicolumn{4}{|c|}{$\begin{array}{c}\text { Total respondents } \\
(\mathrm{N}=\mathbf{2 4 0})\end{array}$} & \multirow[t]{3}{*}{$\begin{array}{l}\text { Wilcoxon } \\
\text { ( } Z \text { value) }\end{array}$} \\
\hline & & \multicolumn{2}{|c|}{$\begin{array}{c}\text { Farmers } \\
(\mathbf{n}=\mathbf{8 0})\end{array}$} & \multicolumn{2}{|c|}{$\begin{array}{c}\text { Farm women } \\
(n=80)\end{array}$} & \multicolumn{2}{|c|}{$\begin{array}{c}\text { Farmers } \\
(n=40)\end{array}$} & \multicolumn{2}{|c|}{$\begin{array}{l}\text { Farm women } \\
(n=40)\end{array}$} & \multicolumn{2}{|c|}{$\begin{array}{c}\text { Farmers } \\
(\mathbf{n}=120)\end{array}$} & \multicolumn{2}{|c|}{$\begin{array}{c}\text { Farm women } \\
(n=120)\end{array}$} & \\
\hline & & MPS & Rank & MPS & Rank & MPS & Rank & MPS & Rank & MPS & Rank & MPS & Rank & \\
\hline 1. & $\begin{array}{l}\text { Personal } \\
\text { contact with } \\
\mathrm{AO} / \mathrm{AAO}\end{array}$ & 66.30 & VIII & 63.80 & IX & 71.30 & VII & 67.50 & IX & 68.80 & VII & 65.65 & VIII & $2.15^{*}$ \\
\hline 2. & $\begin{array}{l}\text { Personal } \\
\text { Contact with } \\
\text { AHO/ HA }\end{array}$ & 67.50 & VI & 65.00 & VIII & 68.75 & VIII & 68.75 & VIII & 68.13 & VIII & 66.88 & VII & $2.53^{*}$ \\
\hline 3. & $\begin{array}{l}\text { Personal } \\
\text { letter }\end{array}$ & 60.60 & XIII & 68.10 & V & 61.30 & XII & 57.50 & XIII & 60.95 & XII & 62.80 & XI & $3.29^{*}$ \\
\hline 4 & Office call & 66.90 & VII & 59.40 & XIII & 73.80 & VI & 65.00 & $\mathrm{X}$ & 70.35 & VI & 62.20 & XII & $3.17^{*}$ \\
\hline 5 & $\begin{array}{l}\text { Telephone } \\
\text { call }\end{array}$ & 68.80 & $\mathrm{~V}$ & 67.50 & VI & 76.30 & $\mathrm{~V}$ & 70.00 & VI & 72.55 & $\mathrm{~V}$ & 68.75 & VI & $3.66^{*}$ \\
\hline 6 & $\begin{array}{l}\text { Contact with } \\
\text { progressive } \\
\text { farmers }\end{array}$ & 77.50 & I & 72.50 & I & 83.80 & I & 80.00 & I & 80.65 & I & 76.25 & I & $2.01^{*}$ \\
\hline 7 & $\begin{array}{l}\text { Contact with } \\
\text { Agro } \\
\text { Service } \\
\text { Centers }\end{array}$ & 70.60 & IV & 66.90 & VII & 78.00 & IV & 74.00 & IV & 74.30 & IV & 70.45 & IV & $3.03^{*}$ \\
\hline 8 & $\begin{array}{l}\text { Friends and } \\
\text { neighbours }\end{array}$ & 74.40 & II & 70.60 & II & 81.30 & II & 77.50 & II & 77.85 & II & 74.05 & II & $2.94 *$ \\
\hline 9 & $\begin{array}{l}\text { University/ } \\
\text { KVK } \\
\text { scientist }\end{array}$ & 72.50 & III & 69.40 & III & 80.00 & III & 76.30 & III & 76.25 & III & 72.85 & III & $1.36 \mathrm{NS}$ \\
\hline 10 & $\begin{array}{l}\text { Private } \\
\text { extension } \\
\text { officer }\end{array}$ & 65.00 & IX & 68.80 & IV & 67.50 & IX & 71.30 & V & 66.25 & IX & 70.05 & V & $1.40 \mathrm{NS}$ \\
\hline 11 & $\begin{array}{l}\text { Farm and } \\
\text { home visit }\end{array}$ & 63.10 & XI & 62.50 & $\mathrm{X}$ & 63.80 & XI & 63.80 & XI & 63.45 & XI & 63.15 & $\mathrm{X}$ & $2.80^{*}$ \\
\hline 12 & Farmers cell & 63.80 & $\mathrm{X}$ & 61.90 & XI & 66.00 & $\mathrm{X}$ & 61.00 & XII & 64.90 & $\mathrm{X}$ & 61.45 & XIII & $3.04 *$ \\
\hline 13 & Farm clinic & 61.90 & XII & 61.30 & XII & 60.00 & XIII & 68.80 & VII & 60.95 & XII & 65.05 & IX & $2.20^{*}$ \\
\hline & Overall & 67.61 & & 65.98 & & 71.68 & & 69.34 & & 69.64 & & 67.66 & & $2.58 *$ \\
\hline
\end{tabular}

NS = Non-significant

$*=$ significant at 5 per cent level of significance 
Table.3 Agriculture information seeking behaviour of the aonla growers with respect to their sources of group

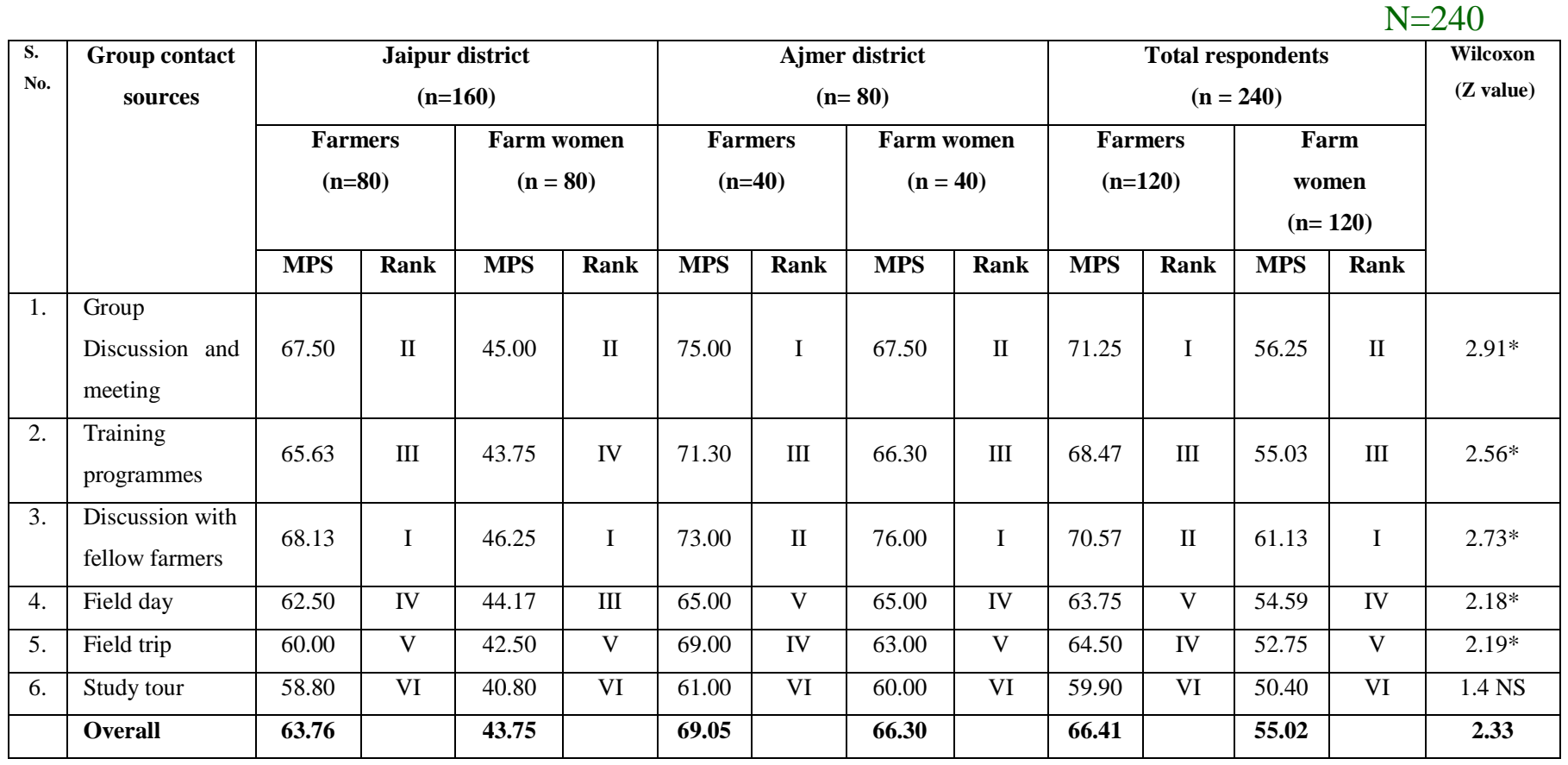

$\mathrm{NS}=$ Non-significant $*=$ significant at 5 per cent level of significance

Table.4 Agriculture information seeking behaviour of the aonla growers with respect to their sources of mass media

\begin{tabular}{|c|c|c|c|c|c|c|c|c|c|c|c|c|c|c|}
\hline & & & & & & & & & & & & & & $\mathrm{N}=240$ \\
\hline S. & & & pur dis & ict $(n=1$ & & & mer dis & ict $(n=$ & & Tot & respon & nts (N) & 240) & Wilcoxon \\
\hline No. & $\begin{array}{l}\text { contact } \\
\text { sources }\end{array}$ & & & $\begin{array}{r}\text { Farm } \\
(\mathbf{n}\end{array}$ & $\begin{array}{l}\text { omen } \\
\text { 80) }\end{array}$ & & & $\begin{array}{r}\text { Farm } \\
(\mathbf{n}\end{array}$ & $\begin{array}{l}\text { vomen } \\
40)\end{array}$ & & & $\begin{array}{r}\text { Farm } \\
(\mathbf{n}=\end{array}$ & $\begin{array}{l}\text { omen } \\
\text { 20) }\end{array}$ & ( $\mathrm{Z}$ value) \\
\hline & & MPS & Rank & MPS & Rank & MPS & Rank & MPS & Rank & MPS & Rank & MPS & Rank & \\
\hline 1. & Radio & 66.88 & III & 43.75 & III & 71.00 & II & 68.00 & III & 68.94 & II & 55.88 & III & $1.25 \mathrm{NS}$ \\
\hline 2. & Television & 68.13 & I & 45.42 & I & 73.80 & I & 76.00 & I & 70.97 & I & 60.71 & I & $2.12^{*}$ \\
\hline 3. & News paper & 67.50 & II & 42.90 & IV & 68.80 & III & 63.80 & $\mathrm{~V}$ & 68.15 & III & 53.35 & $\mathrm{~V}$ & $2.73^{*}$ \\
\hline 4 & $\begin{array}{l}\text { Agricultural } \\
\text { magazine }\end{array}$ & 61.90 & VII & 39.60 & VIII & 64.00 & VI & 59.00 & VII & 62.95 & VI & 49.30 & VII & $2.83^{*}$ \\
\hline 5 & $\begin{array}{l}\text { Krishi mela } \\
\text { / Exhibition }\end{array}$ & 63.80 & IV & 44.20 & II & 66.30 & IV & 72.50 & II & 65.05 & IV & 58.35 & II & $2.72^{*}$ \\
\hline 6 & Internet & 63.75 & $\mathrm{~V}$ & 42.50 & $\mathrm{~V}$ & 56.00 & IX & 54.00 & IX & 59.88 & VIII & 49.25 & VIII & $2.80^{*}$ \\
\hline 7 & $\begin{array}{l}\text { Mobile } \\
\text { phone }\end{array}$ & 62.50 & VI & 41.67 & VI & 65.00 & V & 66.00 & IV & 63.75 & V & 53.84 & IV & $1.97^{*}$ \\
\hline 8 & $\begin{array}{l}\text { Farm } \\
\text { publication }\end{array}$ & 59.40 & VIII & 40.40 & VII & 61.00 & VII & 61.00 & VI & 60.20 & VII & 50.70 & VI & $1.76 \mathrm{NS}$ \\
\hline 9 & $\begin{array}{l}\text { Agriculture } \\
\text { Journal, } \\
\text { magazine }\end{array}$ & 57.50 & IX & 38.75 & IX & 59.00 & VIII & 58.00 & VIII & 58.25 & IX & 48.38 & IX & $2.50^{*}$ \\
\hline & Overall & 63.48 & & 42.13 & & 64.99 & & 64.26 & & 64.24 & & 53.31 & & 2.30* \\
\hline
\end{tabular}

$\mathrm{NS}=$ Non-significant $*=$ significant at 5 per cent level of significanc 
Table.5 Agriculture information evaluation behaviour of the aonla growers with respect to their act performed for evaluation of agriculture information

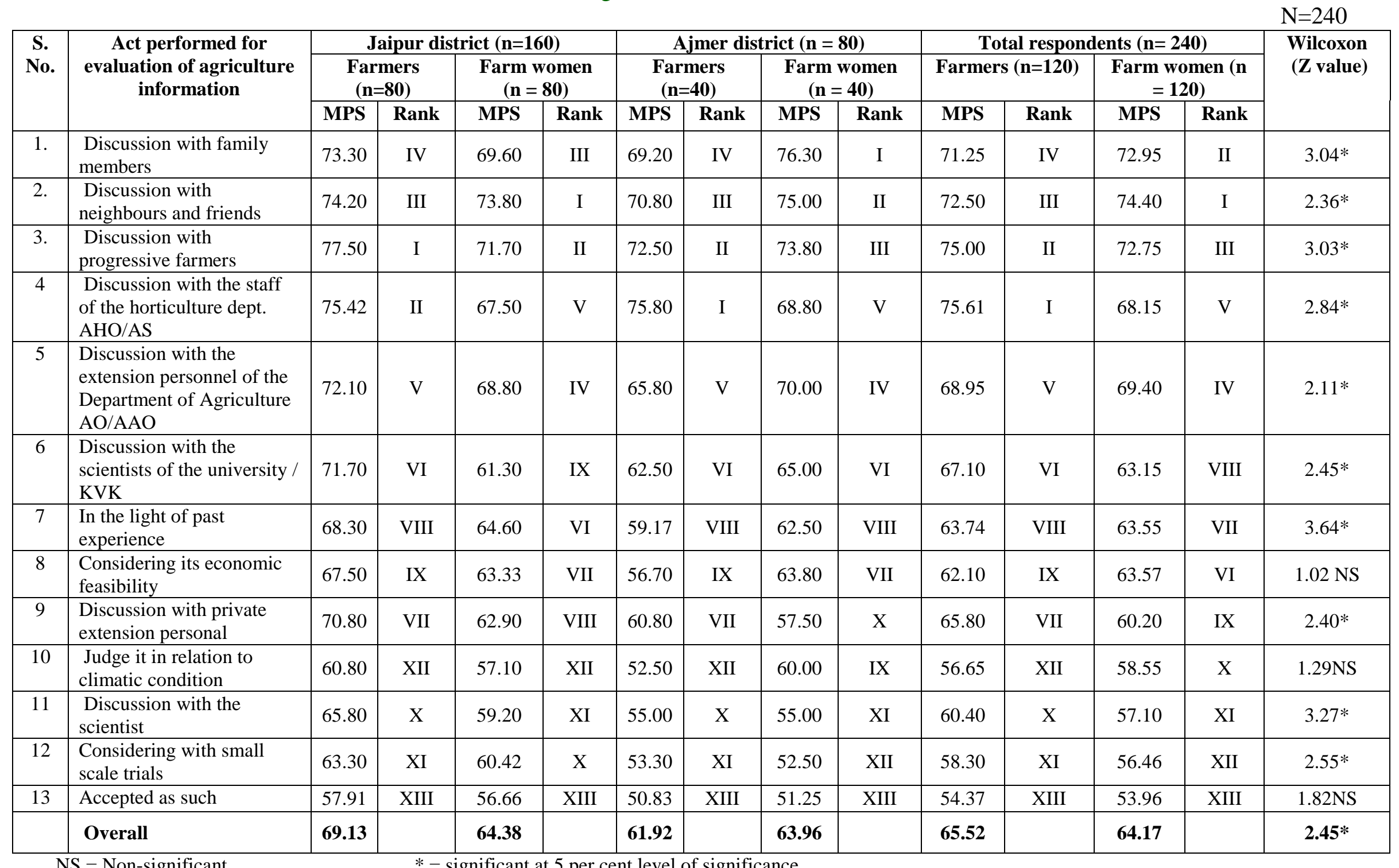


Table.6 Agriculture information evaluation behaviour consideration of different parameters used for evaluation of information

\begin{tabular}{|c|c|c|c|c|c|c|c|c|c|c|c|c|c|c|}
\hline \multirow{4}{*}{$\begin{array}{l}\text { S. } \\
\text { No. }\end{array}$} & & & & & & & & & & & & & & 240 \\
\hline & \multirow{3}{*}{$\begin{array}{c}\text { parameters for } \\
\text { evaluation of } \\
\text { information }\end{array}$} & \multicolumn{4}{|c|}{$\begin{array}{c}\text { Jaipur district } \\
\quad(n=160)\end{array}$} & \multicolumn{4}{|c|}{$\begin{array}{l}\text { Ajmer district } \\
\quad(n=80)\end{array}$} & \multicolumn{4}{|c|}{$\begin{array}{l}\text { Total respondents } \\
\qquad(\mathrm{n}=\mathbf{2 4 0})\end{array}$} & \multirow{3}{*}{$\begin{array}{l}\text { Wilcoxn } \\
\quad(\mathrm{Z} \\
\text { value })\end{array}$} \\
\hline & & \multicolumn{2}{|c|}{$\begin{array}{c}\begin{array}{c}\text { Farmers } \\
(\mathrm{n}=80)\end{array} \\
\end{array}$} & \multicolumn{2}{|c|}{$\begin{array}{l}\text { Farm women } \\
\quad(\mathbf{n}=\mathbf{8 0})\end{array}$} & \multicolumn{2}{|c|}{$\begin{array}{c}\text { Farmers } \\
(n=40)\end{array}$} & \multicolumn{2}{|c|}{$\begin{array}{l}\text { Farm women } \\
\quad(n=40)\end{array}$} & \multicolumn{2}{|c|}{$\begin{array}{l}\text { Farmers } \\
(\mathrm{n}=120)\end{array}$} & \multicolumn{2}{|c|}{$\begin{array}{c}\text { Farm women } \\
(\mathbf{n}=120)\end{array}$} & \\
\hline & & MPS & $\begin{array}{c}\text { Ran } \\
\mathbf{k}\end{array}$ & MPS & $\begin{array}{c}\text { Ran } \\
\mathbf{k}\end{array}$ & MPS & $\begin{array}{c}\text { Ran } \\
\mathbf{k}\end{array}$ & MPS & $\begin{array}{c}\text { Ran } \\
\mathbf{k}\end{array}$ & MPS & $\begin{array}{c}\text { Ran } \\
k\end{array}$ & $\begin{array}{c}\text { Ran } \\
\mathbf{k}\end{array}$ & $\begin{array}{c}\text { Ran } \\
\mathbf{k}\end{array}$ & \\
\hline 1. & $\begin{array}{l}\text { Profitability } \\
\text { from } \\
\text { innovations }\end{array}$ & 79.60 & I & 78.80 & I & 77.55 & II & 72.50 & III & 78.55 & 2 & 75.65 & II & $2.91^{*}$ \\
\hline 2. & $\begin{array}{l}\text { Method of } \\
\text { doing planting }\end{array}$ & 78.30 & II & 77.50 & II & 79.17 & I & 77.50 & I & 78.74 & I & 77.50 & I & $2.46^{*}$ \\
\hline 3. & $\begin{array}{l}\text { Availability of } \\
\text { inputs }\end{array}$ & 73.80 & III & 72.50 & III & 76.70 & III & 75.00 & II & 75.25 & III & 73.75 & III & $2.78^{*}$ \\
\hline 4 & Observability/ & 72.10 & $\mathrm{~V}$ & 67.50 & VII & 72.50 & IV & 70.80 & IV & 72.30 & IV & 69.15 & IV & $1.62 \mathrm{NS}$ \\
\hline 5 & Predictability & 69.68 & VI & 69.58 & IV & 70.80 & $\mathrm{~V}$ & 65.80 & VI & 70.24 & $\mathrm{~V}$ & 67.69 & VI & $2.78^{*}$ \\
\hline 6 & Triability & 69.17 & VI & 68.33 & $\mathrm{~V}$ & 69.20 & VI & 67.50 & $\mathrm{~V}$ & 69.19 & VI & 67.92 & $\mathrm{~V}$ & $2.40^{*}$ \\
\hline 7 & Complxity & 68.33 & VII & 67.68 & VI & 65.83 & VII & 63.33 & VII & 67.08 & VII & 65.51 & VII & $0.98 \mathrm{NS}$ \\
\hline & Overall & 73.00 & & 71.70 & & 73.10 & & 70.35 & & 73.05 & & 71.02 & & $2.28^{*}$ \\
\hline
\end{tabular}

Table.7 Agriculture information evaluation behaviour action taken by anola growers befor using the agriculture information

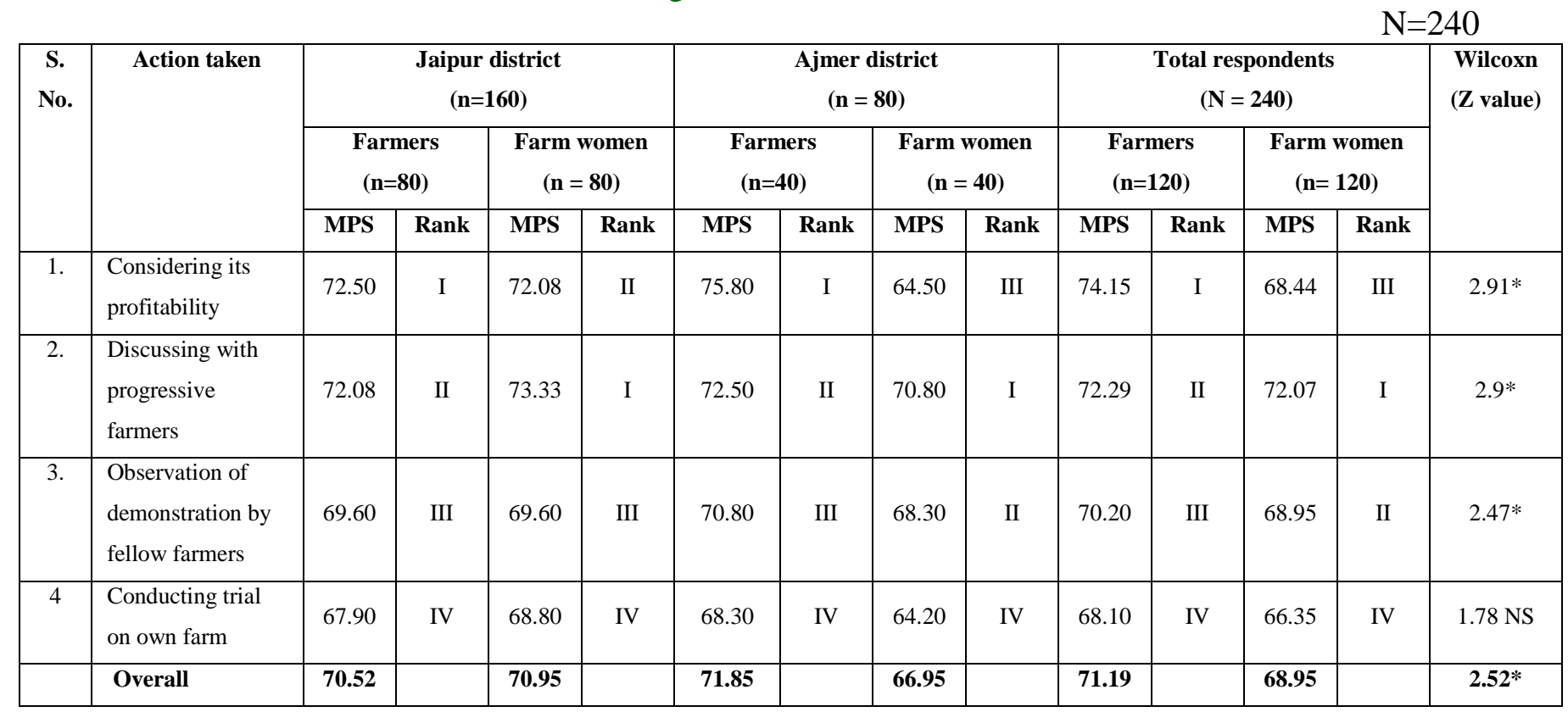

$\mathrm{NS}=$ Non-significant $*=$ significant at 5 per cent level of significance 
Table.8 Agriculture information preservation behaviour of the aonla growers with respect to different methods for information retention

\begin{tabular}{|c|c|c|c|c|c|c|c|c|c|c|c|c|c|c|}
\hline \multicolumn{15}{|c|}{$\mathrm{N}=240$} \\
\hline \multirow[t]{3}{*}{$\begin{array}{c}\text { S. } \\
\text { No. }\end{array}$} & \multirow{3}{*}{$\begin{array}{l}\text { Methods for } \\
\text { information } \\
\text { retention }\end{array}$} & \multicolumn{4}{|c|}{$\begin{array}{c}\text { Jaipur district } \\
(\mathrm{n}=\mathbf{1 6 0})\end{array}$} & \multicolumn{4}{|c|}{$\begin{array}{l}\text { Ajmer district } \\
(\mathrm{n}=\mathbf{8 0})\end{array}$} & \multicolumn{4}{|c|}{$\begin{array}{l}\text { Total respondents } \\
\quad(\mathrm{N}=\mathbf{2 4 0})\end{array}$} & \multirow{2}{*}{$\begin{array}{c}\text { Wilcoxo } \\
\mathbf{n}(\mathbf{Z} \\
\text { value }) \\
\end{array}$} \\
\hline & & \multicolumn{2}{|c|}{$\begin{array}{c}\text { Farmers } \\
(\mathbf{n}=\mathbf{8 0})\end{array}$} & \multicolumn{2}{|c|}{$\begin{array}{l}\text { Farm women } \\
(\mathbf{n}=\mathbf{8 0})\end{array}$} & \multicolumn{2}{|c|}{$\begin{array}{c}\text { Farmers } \\
(n=40)\end{array}$} & \multicolumn{2}{|c|}{$\begin{array}{l}\text { Farm women } \\
(\mathrm{n}=40)\end{array}$} & \multicolumn{2}{|c|}{$\begin{array}{c}\text { Farmers } \\
(\mathbf{n}=120)\end{array}$} & \multicolumn{2}{|c|}{$\begin{array}{c}\text { Farm women } \\
(n=120)\end{array}$} & \\
\hline & & MPS & Rank & MPS & Rank & MPS & Rank & MPS & Rank & MPS & Rank & MPS & Rank & \\
\hline 1. & Memorizing & 72.90 & IV & 67.50 & III & 68.30 & VI & 74.20 & III & 70.60 & $\mathrm{~V}$ & 70.85 & III & $2.51 *$ \\
\hline 2. & $\begin{array}{l}\text { Taking down in a } \\
\text { note book/diary }\end{array}$ & 40.80 & VIII & 62.92 & VIII & 64.17 & VIII & 64.17 & VIII & 52.49 & VIII & 63.55 & VIII & $3.44 *$ \\
\hline 4 & $\begin{array}{l}\text { Preserve the news } \\
\text { paper cutting }\end{array}$ & 70.00 & V & 65.00 & V & 79.20 & II & 69.20 & V & 74.60 & III & 67.10 & V & $2.03 *$ \\
\hline 7 & $\begin{array}{l}\text { By maintaining a } \\
\text { special file }\end{array}$ & 67.08 & VII & 63.33 & VII & 66.67 & VII & 65.83 & VII & 66.88 & VII & 64.58 & VII & $1.29 \mathrm{NS}$ \\
\hline 8 & $\begin{array}{l}\text { By practicing in } \\
\text { daily life }\end{array}$ & 68.30 & VI & 77.10 & II & 70.00 & V & 75.80 & II & 69.15 & VI & 76.45 & II & $1.17 \mathrm{NS}$ \\
\hline & Overall & 67.90 & & 68.17 & & 72.39 & & 70.94 & & 70.15 & & 69.55 & & $2.21 *$ \\
\hline
\end{tabular}

NS = Non-significant

$*=$ significant at 5 per cent level of significance

Table.9 Agriculture Information utilization behaviour of the aonla growers with respect to different operations carried out for using the agriculture information

\begin{tabular}{|c|c|c|c|c|c|c|c|c|c|c|c|c|c|c|}
\hline \multirow{4}{*}{\begin{tabular}{|c|} 
S. \\
No.
\end{tabular}} & \multirow{4}{*}{$\begin{array}{c}\text { Operations } \\
\text { carried out for } \\
\text { using the } \\
\text { information }\end{array}$} & & & & & & & & & & & & & $=240$ \\
\hline & & \multicolumn{4}{|c|}{$\begin{array}{c}\text { Jaipur district } \\
(n=160)\end{array}$} & \multicolumn{4}{|c|}{$\begin{array}{c}\text { Ajmer district } \\
(n=80)\end{array}$} & \multicolumn{4}{|c|}{$\begin{array}{c}\text { Total respondents } \\
(\mathbf{N}=\mathbf{2 4 0})\end{array}$} & \multirow[t]{3}{*}{$\begin{array}{l}\text { Wilcoxon } \\
\text { (Z value) }\end{array}$} \\
\hline & & \multicolumn{2}{|c|}{$\begin{array}{c}\text { Farmers } \\
(\mathbf{n}=\mathbf{8 0})\end{array}$} & \multicolumn{2}{|c|}{$\begin{array}{c}\text { Farm women } \\
(\mathbf{n}=\mathbf{8 0})\end{array}$} & \multicolumn{2}{|c|}{$\begin{array}{c}\text { Farmers } \\
(n=40)\end{array}$} & \multicolumn{2}{|c|}{$\begin{array}{l}\text { Farm women } \\
(n=40)\end{array}$} & \multicolumn{2}{|c|}{$\begin{array}{c}\text { Farmers } \\
(\mathbf{n}=120)\end{array}$} & \multicolumn{2}{|c|}{$\begin{array}{l}\text { Farm women } \\
(\mathbf{n}=\mathbf{1 2 0})\end{array}$} & \\
\hline & & MPS & Rank & MPS & Rank & MPS & Rank & MPS & Rank & MPS & Rank & MPS & Rank & \\
\hline 1. & Pit preparation & 83.80 & III & 78.30 & IV & 72.50 & IV & 70.00 & III & 78.15 & III & 74.15 & IV & $2.83^{*}$ \\
\hline 2. & $\begin{array}{l}\text { Selection of } \\
\text { seed material }\end{array}$ & 85.80 & II & 80.40 & II & 75.00 & II & 77.50 & I & 80.40 & II & 78.95 & I & $3.35^{*}$ \\
\hline 3. & Varieties & 88.30 & I & 81.30 & I & 78.23 & I & 74.10 & II & 83.27 & I & 77.70 & II & $3.46^{*}$ \\
\hline 4 & Propagation & 82.50 & IV & 79.20 & III & 69.20 & VI & 69.20 & IV & 75.85 & VI & 74.20 & III & $2.93^{*}$ \\
\hline 5 & Plantation & 82.10 & $\mathrm{~V}$ & 77.50 & $\mathrm{~V}$ & 70.80 & $\mathrm{~V}$ & 67.50 & $\mathrm{~V}$ & 76.45 & IV & 72.50 & $\mathrm{~V}$ & $3.30^{*}$ \\
\hline 6 & $\begin{array}{l}\text { Hoeing and } \\
\text { weeding }\end{array}$ & 79.20 & VII & 76.70 & VI & 65.83 & VIII & 63.33 & VII & 72.52 & VIII & 70.02 & VII & $2.85^{*}$ \\
\hline 7 & Irrigation & 80.00 & VI & 75.80 & VII & 68.33 & VII & 66.67 & VI & 74.17 & VII & 71.24 & VI & $3.34 *$ \\
\hline 8 & Intercropping & 75.40 & IX & 73.30 & IX & 60.00 & $\mathrm{X}$ & 61.70 & VIII & 67.70 & $X$ & 67.50 & VIII & $1.82 \mathrm{NS}$ \\
\hline 9 & $\begin{array}{l}\text { Manure and } \\
\text { fertilizer } \\
\text { management }\end{array}$ & 78.30 & VIII & 74.20 & VIII & 74.20 & III & 60.00 & IX & 76.25 & V & 67.10 & IX & $1.55 \mathrm{NS}$ \\
\hline 10 & $\begin{array}{l}\text { Training/ } \\
\text { pruning }\end{array}$ & 70.40 & XI & 71.30 & $X$ & 58.30 & XI & 59.20 & $X$ & 64.35 & XI & 65.25 & $\mathrm{X}$ & $2.78^{*}$ \\
\hline 11 & $\begin{array}{l}\text { Harvesting and } \\
\text { Grading }\end{array}$ & 74.17 & $\mathrm{X}$ & 70.42 & XI & 62.50 & IX & 58.33 & XI & 68.34 & IX & 64.38 & XI & $2.02 *$ \\
\hline \multirow[t]{2}{*}{12} & $\begin{array}{l}\text { Marketing } \\
\text { operations }\end{array}$ & 70.80 & XII & 68.30 & XII & 55.10 & XII & 55.00 & XII & 62.95 & XII & 61.65 & XII & $2.44^{*}$ \\
\hline & Overall & 79.02 & & 75.77 & & 67.49 & & 65.24 & & 73.26 & & 70.50 & & $2.72^{*}$ \\
\hline
\end{tabular}

NS = Non-significant

$*=$ significant at 5 per cent level of significance 
Table.10 Information dissemination behaviour of the aonla growers with respect to their disseminating agriculture information

\begin{tabular}{|c|c|c|c|c|c|c|c|c|c|c|c|c|c|c|}
\hline \multirow{3}{*}{$\begin{array}{l}\text { S. } \\
\text { No } \\
\text { • }\end{array}$} & \multirow[t]{3}{*}{ Disseminating } & \multicolumn{4}{|c|}{$\begin{array}{c}\text { Jaipur district } \\
(n=160)\end{array}$} & \multicolumn{4}{|c|}{$\begin{array}{l}\text { Ajmer district } \\
(\mathbf{n}=\mathbf{8 0})\end{array}$} & \multicolumn{4}{|c|}{$\begin{array}{l}\text { Total respondents } \\
\quad(\mathbf{N}=\mathbf{2 4 0})\end{array}$} & \multirow{3}{*}{$\begin{array}{c}\text { Wilcoxo } \\
\text { n }(\mathbf{Z} \\
\text { value })\end{array}$} \\
\hline & & \multicolumn{2}{|c|}{$\begin{array}{c}\text { Farmers } \\
(\mathbf{n}=\mathbf{8 0})\end{array}$} & \multicolumn{2}{|c|}{$\begin{array}{c}\text { Farm women } \\
(\mathbf{n}=\mathbf{8 0})\end{array}$} & \multicolumn{2}{|c|}{$\begin{array}{c}\text { Farmers } \\
(n=40)\end{array}$} & \multicolumn{2}{|c|}{$\begin{array}{l}\text { Farm women } \\
(\mathrm{n}=40)\end{array}$} & \multicolumn{2}{|c|}{$\begin{array}{c}\text { Farmers } \\
(\mathbf{n}=120)\end{array}$} & \multicolumn{2}{|c|}{$\begin{array}{c}\text { Farm women } \\
(\mathbf{n}=120)\end{array}$} & \\
\hline & & MPS & $\begin{array}{c}\text { Ran } \\
\mathbf{k}\end{array}$ & MPS & $\begin{array}{c}\text { Ran } \\
\mathbf{k}\end{array}$ & MPS & $\begin{array}{c}\operatorname{Ran} \\
\mathbf{k}\end{array}$ & MPS & $\begin{array}{c}\text { Ran } \\
\mathbf{k}\end{array}$ & MPS & $\begin{array}{c}\text { Ran } \\
\mathbf{k}\end{array}$ & MPS & $\begin{array}{c}\text { Ran } \\
\mathbf{k}\end{array}$ & \\
\hline 1. & $\begin{array}{l}\text { Discussion with } \\
\text { neighbouring } \\
\text { farmer }\end{array}$ & 69.40 & II & 68.80 & II & 67.50 & I & 68.80 & II & 68.45 & I & 68.80 & II & $2.79^{*}$ \\
\hline 2. & $\begin{array}{l}\text { Discussion with } \\
\text { progressive } \\
\text { farmers }\end{array}$ & 70.00 & I & 69.38 & I & 65.00 & III & 70.00 & I & 67.50 & II & 69.69 & $\mathrm{I}$ & $2.54 *$ \\
\hline 3. & $\begin{array}{l}\text { Participating in } \\
\text { demonstrations } \\
\text { and field trials }\end{array}$ & 68.80 & III & 63.80 & VI & 60.00 & V & 67.50 & III & 64.40 & IV & 65.65 & III & $2.79^{*}$ \\
\hline 4 & $\begin{array}{l}\text { Participating in } \\
\text { farmers training } \\
\text { programmes }\end{array}$ & 65.00 & V & 67.50 & III & 63.80 & IV & 63.80 & IV & 64.40 & IV & 65.65 & III & $2.42^{*}$ \\
\hline 5 & $\begin{array}{l}\text { Participating in } \\
\text { Krishi mela }\end{array}$ & 63.80 & VI & 66.30 & IV & 67.50 & I & 62.50 & $\mathrm{~V}$ & 65.65 & III & 64.40 & $\mathrm{~V}$ & $2.03 *$ \\
\hline 6 & $\begin{array}{l}\text { Participating in } \\
\text { TV and radio } \\
\text { programmes }\end{array}$ & 66.88 & IV & 61.25 & VII & 53.75 & VII & 58.75 & VII & 60.32 & $\begin{array}{ll}\text { VI } \\
\end{array}$ & 60.00 & VII & $2.26^{*}$ \\
\hline 7 & $\begin{array}{l}\text { Writing in news } \\
\text { papers }\end{array}$ & 63.75 & VII & 60.63 & VIII & 51.25 & VIII & 56.25 & VIII & 57.50 & VIII & 58.44 & VIII & $2.41^{*}$ \\
\hline \multirow[t]{2}{*}{8} & $\begin{array}{l}\text { Discussion with } \\
\text { relatives }\end{array}$ & 62.50 & VIII & 65.62 & V & 56.25 & VI & 60.00 & VI & 59.38 & VII & 62.81 & VI & $1.66 \mathrm{NS}$ \\
\hline & Overall & 66.27 & & 65.41 & & 60.63 & & 63.45 & & 63.45 & & 64.43 & & $2.36 *$ \\
\hline
\end{tabular}

$\mathrm{NS}=$ Non-significant $*$ significant at 5 per cent level of significance

Hence, the null hypothesis was accepted and alternate hypothesis was rejected, which leads to the conclusion that there is no significant difference between aonla growing farmers and farm women with respect to their Agriculture Information Evaluation Behaviour regarding these considerations of different parameters used for evaluation of information.

The data presented in Table 2.2 indicates that for aonla growing farmers and farm women "method of doing planting" (MPS 78.74and 77.50 respectively) and "profitability of innovations" (MPS 78.55 and 75.65 respectively) were the major consideration of different parameters used for evaluation of agriculture information used by majority of the anola growers and accorded first and second ranks respectively. It also revealed that aonla growing farmers and farm women "complxity" (MPS 67.08 and 65.51 respectively) was the least preferred information source as perceived by the respondents.

\section{Agriculture Information Evaluation} Behaviour of the aonla growers with respect to their action taken by anola growers before using the information

The data related Agriculture Information Evaluation Behaviour of the aonla growing farmers and farm women with respect to their action taken by anola growers before using the information incorporated in Table 2.3 shows that calculated Wilcoxen ' $Z$ ' value for the action taken by anola growers before using the information viz. "considering its profitability', 'discussing with progressive 
farmers' and 'observation of demonstration by fellow farmers'were more than the tabulated value at 5 per cent level of significance. Hence, the null hypothesis was rejected and alternate hypothesis was accepted, which leads to the conclusion that there is a significant difference between aonla growing farmers and farm women with respect to their Agriculture Information Evaluation Behaviour regarding these actions taken by anola growers before using the information. Whereas the calculated Wilcoxen ' $Z$ ' value for the 'conducting trial on own farm' was less than the tabulated value at 5 per cent level of significance.

Hence, the null hypothesis was accepted and alternate hypothesis was rejected, which leads to the conclusion that there is no significant difference between aonla growing farmers and farm women with respect to their Agriculture Information Evaluation Behaviour regarding this action taken by anola growers before using the information.

The data presented in Table 2.3 indicates that for aonla growing farmers "considering its profitability" (MPS 74.15) and for farm women "discussing with progressive farmers" (MPS 72.07) were the major action taken by anola growers before using the agriculture information used by majority of the anola growers and accorded first rank, whereas, for aonla growing farmers "discussing with progressive farmers" (MPS 72.29) and for farm women "observation of demonstration by follow farmers" (MPS 68.95) were the major action taken by anola growers before using the agriculture information used by majority of the anola growers and accorded second rank respectively. It also revealed that for anola growing farmers and farm women "conducting trail on own farm" (MPS 68.10 and 66.65 respectively) was the least preferred information source as perceived by the respondents.
It was observed that methods like discussion with staff of horticulture and agriculture department and discussion with scientists of the university were relatively employed by the less number of respondents. This may be due to the fact that they donot visit the farmers field regularly and farmers do not consult them for getting information.

\section{Agriculture Information Preservation Behaviour of the aonla growers}

The data related with Agriculture Information Preservation Behaviour of the aonla growing farmers and farm women with respect to their method of information retention were incorporated in Table 3 shows that calculated Wilcoxen ' $Z$ ' value for the method of information retention viz. 'memorizing', 'taking down in a note book/diary', 'preserve the printed literature like leaflets', bulletins, booklets at a safe place', 'preserve the newspaper cutting', 'preserve the information in CD/floppy / soft copy' and 'telling family members to remember' were more than the tabulated value at 5 per cent level of significance.

Hence, the null hypothesis was rejected and alternate hypothesis was accepted, which leads to the conclusion that there is a significant difference between aonla growing farmers and farm women with respect to these methods of information retention. Whereas the calculated Wilcoxen ' $Z$ ' value for the method of information retention viz. by maintaining a special file and by practicing in daily life were less than the tabulated value at 5 per cent level of significance.

Hence, the null hypothesis was accepted and alternate hypothesis was rejected, which leads to the conclusion that there is no significant difference between aonla growing farmers and farm women with respect to these methods of information retention. 
The data presented in Table 3 indicates that for aonla growing farmers "Preserve the printed literature like leaflets, bulletins, booklets at a safe place" (MPS 77.90) and for farm women "Telling family members to remember" (MPS 78.85) were the major preservation/storage behaviour of agriculture information used by majority of the anola growers and accorded first rank, whereas, for aonla growing farmers "Preserve the information in CD/floppy / soft copy" (MPS 76.65) and for farm women "By practicing in daily life" (MPS 76.45) were the major preservation/storage behaviour of agriculture information used by majority of the anola growers and accorded second rank respectively.

It also revealed that for anola growing farmers and farm women "Taking down in a note book/diary" (MPS 63.55 and 52.49 respectively) was the least preferred information source as perceived by the respondents.

Only few of the respondents preserve the information in note book/diary may be due to availability of needed information in note book/diary is limited and not easily available and lack of awareness about these methods. This may be available only during Krishi mela but very limited information with respect to aonla crops and also lack of facilities to retrieve the stored information.

\section{Agriculture Information Utilization Behaviour of the aonla grower}

The data related with Agriculture Information Utilization Behaviour of the aonla growing farmers and farm women with respect to their operations carried out for using the information incorporated in Table 4 shows that calculated Wilcoxen ' $Z$ ' value for the operations carried out by for using the information viz. 'pit preparation', 'selection of seed material', 'varieties', 'propagation', 'plantation', 'hoeing and weeding', 'irrigation, 'training / pruning', 'harvesting and grading', and 'marketing operations' were more than the tabulated value at 5 per cent level of significance. Hence, the null hypothesis was rejected and alternate hypothesis was accepted, which leads to the conclusion that there is a significant difference between aonla growing farmers and farm women with respect to these operations carried out for using the information. Whereas the calculated Wilcoxen ' $Z$ ' value for the operations carried out for using the information viz. 'intercropping' and 'manure and fertilizer management' were less than the tabulated value at 5 per cent level of significance.

Hence, the null hypothesis was accepted and alternate hypothesis was rejected, which leads to the conclusion that there is no significant difference between aonla growing farmers and farm women with respect to these operations carried out for using the information.

The data presented in Table 4 indicates that for aonla growing farmers "varieties" (MPS 83.27) and for farm women "selection of seed material" (MPS 78.95) were the major utilization behaviour of agriculture information used by majority of the anola growers and accorded first rank. Whereas, for aonla growing farmers "Selection of seed material" (MPS 80.40) and for farm women "varieties" (MPS 77.70) were the major utilization behaviour of agriculture information used by majority of the anola growers and accorded second rank respectively. It also revealed that for anola growing farmers and farm women "Marketing operations" (MPS 62.95 and 61.65 respectively) was the least preferred information source as perceived by the respondents. 


\section{Agriculture Information Dissemination Behaviour of the aonla growers}

The data related with Agriculture Information Dissemination Behaviour of the aonla growing farmers and farm women with respect to their acts of disseminating information incorporated in Table 5.2.5 shows that calculated Wilcoxen ' $Z$ ' value for the acts of disseminating information viz. 'discussion with neighbouring farmer', 'discussion with progressive farmers', 'participating in demonstrations and field trials', 'participating in farmers training programmes', 'participating in Krishi mela', 'participating in TV and radio programmes' and 'writing in news papers' were more than the tabulated value at 5 per cent level of significance. Hence, the null hypothesis was rejected and alternate hypothesis was accepted, which leads to the conclusion that there is a significant difference between aonla growing farmers and farm women with respect to these acts of disseminating information. Whereas the calculated Wilcoxen ' $Z$ ' value for the acts of disseminating information viz. 'discussion with relatives' was less than the tabulated value at 5 per cent level of significance. Hence, the null hypothesis was accepted and alternate hypothesis was rejected, which leads to the conclusion that there is no significant difference between aonla growing farmers and farm women with respect to these acts of disseminating information.

The data presented in Table 5 indicates that for aonla growing farmers "Discussion with neighbouring farmer" (MPS 68.45) and for farm women "Discussion with progressive farmers" (MPS 69.69) were the major dissemination behaviour of agriculture information used by majority of the anola growers and accorded first rank, whereas, for aonla growing farmers "Discussion with progressive farmers" (MPS 67.50) and for farm women "Discussion with neighbouring farmer" (MPS 68.80) were the major dissemination behaviour of agriculture information used by majority of the anola growers and accorded second rank respectively. It also revealed that for anola growing farmers and farm women "Writing in newspapers" (MPS 58.00 and 55.94 respectively) was the least preferred information source as perceived by the respondents.

Results also indicated that method of planting was found to be the major consideration among different parameters used for evaluation of agriculture information by both the aonla growing farmers and farm women.

As the action taken by anola growers before using the agriculture information is concerned it was found that the aonla growing farmers focused on "considering its profitability" whereas, farm women mainly stressed on "discussing with progressive farmers" before using the agriculture information.

Regarding preservation behaviour of agriculture information it was found that the aonla growing farmers used to "Preserve the printed literature like leaflets, bulletins, booklets at a safe place", whereas the farm women were used to preserve the agriculture information by "Telling family members to remember".

Regarding utilization behaviour of agriculture information is concerned it was found that the aonla growing farmers used "varieties". However, the farm women used "selection of seed material" regarding the major information utilization behaviour of agriculture information.

Regarding the major information dissemination behaviour of agriculture information, it was found that the aonla growing farmers used "Discussion with 
neighbouring farmers" and farm women used "Discussion with progressive farmers".

\section{Recommendations}

The study clearly revealed that the agriculture information management behaviour was greatly varied among the respondents of all the aonla growing farmers and farm women. Agriculture Information Seeking Behaviour, Agriculture Information Evaluation Behaviour, Agriculture Information Preservation/Storage Behaviour, Agriculture Information Utilisation Behaviour and Agriculture Information Dissemination Behaviour and the extent of use and degree of credibility of different sources and channels of agriculture information were not similar of all the categories of aonla growers.

So it is not appropriate to apply similar extension and communication strategy for transferring new technologies for different categories of aonla growers.

The technology demand of different category of aonla growers vary greatly, it is suggested that while transferring the technology, resources and socio-economic conditions of aonla growers should be considered.

\section{References}

Dhayal, B. L. (2006). "Communication behaviour of ber growers in Chomu Tehsil of Jaipur District of Rajasthan". M.Sc. Thesis RAU, Bikaner, CampusJobner.

Dhayal, B. L., Khan,I.M. and Jangid, M. K. (2012).'Information seeking information of ber growers in Jaipur District of Rajasthan." Rajasthan Journal of Extension Education, vol. 20, pp. 57-60

Gupta, S. P., Amardeep and Kushal (2003). "Utilization of information source by farmers under different production system in Uttranchal and Uttar Pradesh," Manage Extension Research Review, vol. 4(2), pp. 70-80.

Yadav, B.S. (2009). "Information Seeking Behaviour of Fenugreek Growers in Jaipur Region of Rajasthan." Ph.D. Thesis, RAU, Bikaner, Campus-Jobner

\section{How to cite this article:}

Saroj Choudhary. 2017. Agriculture Information Management Behaviour of Aonla Growers. Int.J.Curr.Microbiol.App.Sci. 6(12): 5395-5411. doi: https://doi.org/10.20546/ijcmas.2017.612.504 